Katarzyna Wądolny-Tatar

\title{
W splocie z przeszłością. Historiografia w literaturze dla dzieci i młodzieży w XXI wieku w perspektywie nowej humanistyki
}

\begin{abstract}
Wądolny-Tatar Katarzyna, W splocie z przeszłością. Historiografia w literaturze dla dzieci i młodzieży w XXI wieku w perspektywie nowej humanistyki [Entangled with the past. Historiography in literature for children and youth in the twenty-first century in the perspective of the new humanities]. „Przestrzenie Teorii” 34. Poznań 2020, Adam Mickiewicz University Press, pp. 267-289. ISSN 1644-6763. DOI 10.14746/pt.2020.34.12.
\end{abstract}

Literature for children and youth is reinterpreted under the influence of the new humanities. For example, prose from the 20th century is subjected to postcolonial read-outs (In Desert and Wilderness [W pustyni i w puszczy] by Henryk Sienkiewicz, the novel cycle by Alfred Szklarski), an eco-critical reading of the works of Tove Jansson, Hugh Lofting and the Polish writers Ludwik Jerzy Kern and Dorota Terakowska is proposed. On the other hand, works based on historical issues create a thematically focused series of publications, genealogical and geanological cycles, which are also fictionalized biographies, separate works referring to the lineage of the Polish state and dynastic linagees, post-memory narratives of a so-called "second generation" about the experience of the Second World War, and works on migration issues. The examples of literary historiography for adolescents mentioned and described in the article, captured in several areas of the formal issues, can be read through the prism of many analytical and interpretative practices, overlapping and incomplete methodologies. Retentional direction of reading, with the horizon of the past inscribed in it, does not exclude a protentional-oriented towards the future and environmental change, motivated by postcolonial revisions of old works, important issues of the 21st century (migration, post-memory), and a non-anthropocentric perception of reality. Their analysis should take into account the "poetics of history", tropology of the narrative and narrative strategies (which Hayden White wrote about). Moreover, entangling the past with the present of the child-reader (and in fact with their future), seems to be a necessary condition for its interiorization, for recognizing it as one's own, for admitting it. It always has a multitemporal, multigenerational and multicultural character.

KEYWORDS: new humanities, literature for children and youth, historiography

Opisując sytuację humanistyki w XXI wieku, Przemysław Czapliński zauważa rezygnację w badaniach $\mathrm{z}$ ujęć transgresyjnych na rzecz subwersywnych, a pola badawcze związane z kategoriami różnicy czy granicy nie tyle sa przekraczane, co rozpoznawane i naukowo spożytkowywane. Figura „zerwania” zostaje zastapiona podkreślajacymi celowość połączenia - „węzłem, „splotem”, „wiązaniem”. Przywołując koncepcję Brunona Latoura, poznański literaturoznawca dostrzega trzy „sploty” nowej humanistyki. 
Pierwszy z nich stanowi rezultat zmiany postępowania badawczego: „[...] w miejsce spójnych, kompletnych, domkniętych metod weszły praktyki. Praktyka łączy eksperyment, zabawę, ryzyko. [...] Badacz zdobywa samowiedzę w procesie, ale wiedzy tej nie daje się trwale oddzielić od badanego

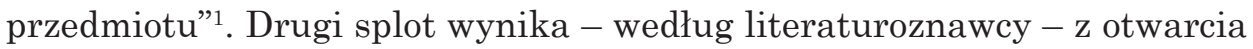
na siebie metod niepełnych, dążenia do unidyscyplinarności nauk. „To nie wielość punktów widzenia jest dzisiaj ambicja humanistyki, lecz raczej badanie wielości linii przebiegających przez jeden punkt, poznawanie niedomknięcia pola, na którym ów punkt się znajduje, śledzenie mnogości śladów tam pozostawionych i interpretowanie nieoczywistości kierunków, ku którym ślady te prowadzą" - powiada Czapliński. Trzeci splot określa środowiskowość nauk, sytuuje badacza wewnątrz tego, co bada, w szczególności określa inwencyjny, a nawet interwencyjny charakter humanistyki w działaniu.

„Splot” zdaje się więc stopniowo zastępować „Zwrot” jako kategorię opisu wielokierunkowości badań. Semantyczny zakres i przydatność tego drugiego terminu były wielokrotnie w humanistyce dyskutowane. Rozpoznawano stan metodologicznego eklektyzmu i polilogiczność humanistyki w ostatniej dekadzie XX wieku i dwóch pierwszych XXI, rozważano możliwości i ograniczenia, wynikające ze stosowania narzędzi badawczych, wypracowanych przez poszczególne zwroty w czytaniu literatury dawnej i nowej ${ }^{3}$. Refleksją ta została objęta także szkoła jako teren dynamicznego współistnienia zróżnicowanych sposobów analizy i interpretacji tekstu, przejawiających się w metodologiach nauczania ${ }^{4}$, oscylujących między sferami przymusu i wolności ${ }^{5}$. Wątek ten podjęła m.in. Krystyna Koziołek, pytając o konsekwencje adaptowania kolejnych zwrotów dla nauczania literatury, ze świadomością że jednym z zadań szkoły jest „zachowanie ciagłości hu-

${ }^{1}$ P. Czapliński, Sploty, [w:] Nowa humanistyka. Zajmowanie pozycji, negocjowanie autonomii, red. P. Czapliński, R. Nycz i in., Warszawa 2017, s. 20.

${ }^{2}$ Tamże, s. 21.

${ }^{3}$ Zob. „Zwroty” badawcze w humanistyce. Konteksty poznawcze, kulturowe i spoteczno-instytucjonalne, red. J. Kowalewski, W. Piasek, Olsztyn 2010. Nie brak tu również krytycznych stanowisk: P. Abriszewska, Stereotyp zwrotu, inflacja przełomów we wspótczesnej humanistyce, [w:] „Zwroty” badawcze..., s. 45-60.

${ }^{4}$ Zob. P. Czapliński, J.B. Bednarek, D. Gostyński, Literatura i jej natury. Przewodnik ekokrytyczny dla nauczycieli i uczniów szkót średnich, Poznań 2017; Adaptacje. Szkolne użycia ponowoczesnych (anty)teorii literatury, red. G.B. Tomaszewska, D. Szczukowski, Gdańsk 2018; G.B. Tomaszewska, Praktyki czytania. Ponowoczesna interpretacja a szkota, Gdańsk 2019.

${ }^{5}$ Odwołuję się tutaj do tytułu rozprawy A.Z. Kłakówny i wyłożonej w niej koncepcji edukacyjnej, zob. A.Z. Kłakówna, Przymus i wolność. Projektowanie procesu ksztatcenia kulturowej kompetencji. Język polski w klasach IV-VI szkoły podstawowej, w gimnazjum i liceum, Kraków 2003. Podobne ramy dla historiografii ustala J. Topolski, Wolność i przymus w tworzeniu historii, wyd. 2, Poznań 2004. 


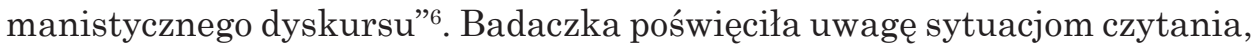
szkolnym praktykom lektury, marginalizującym jej indywidualny tryb. Wypowiadała się o reakcjach na tekst między innymi w kontekście zwrotu etycznego i dyskusji nad „słabym” profesjonalizmem literaturoznawcy (czy szkolnego polonisty):

Tymczasem nawet pozamerytoryczne odczytania utworu dają się wykorzystać dla uświadomienia uczniom, że interpretacja, zwłaszcza „słaba” interpretacja, niszczy estetyczną i semantyczną autonomię wypowiedzi, poddaje ją arbitralnemu wartościowaniu, ocenom etycznym; obnaża obecne w interpretacji: nudę, przyjemność, przemoc, seksualność lub politykę czytania. Nie da się też utrzymać dłużej utopii neutralnego nauczyciela, który miałby być przede wszystkim dysponentem standardowej wiedzy o literaturze oraz metodycznych technik jej dystrybucji. Przeciwnie, „uwolnione” lektury wymagaja od niego improwizacji, refleksu, samodzielnej (ale też samotnej) decyzji w obronie tekstu i reguł jego komentowania ${ }^{7}$.

Literatura dla dzieci i młodzieży, w tym również utwory, które taką adresatywność zyskały w szkolnych programach i podręcznikach, jest odczytywana przez pryzmat kulturowych zwrotów, dostarczających określonego repertuaru pojęć i narzędzi analityczno-interpretacyjnych, co w odniesieniu do dawnych tekstów oznacza rewizję albo przynajmniej korektę dotychczasowych sposobów i stylów odbioru. Ślaskie literaturoznawczynie zaproponowały lekturę geo/topograficzną i ekokrytyczną prozy Tove Jansson i Hugh Loftinga, a także polskich pisarzy: Ludwika Jerzego Kerna, czy ostatnio - Doroty Terakowskiej ${ }^{8}$. W polu zainteresowań badaczy znalazły się także utwory dla dzieci i młodzieży, które poddawały się reintepretacji ze względu na postzależnościowy dyskurs w polskim literaturoznawstwie. Kilku postkolonialnych odczytań doczekał się Murzynek Bambo Juliana Tuwima ${ }^{9}$, dokonano kontekstowej (re)lokacji wybranych powieści przygodowych

${ }^{6} \mathrm{~K}$. Koziołek, Ziemia niczyja. Zwroty badawcze w literaturoznawstwie i ich konsekwencje dla nauczania literatury, „Postscriptum Polonistyczne” 2012, nr 2, s. 109.

${ }^{7}$ Tamże.

${ }^{8}$ Zob. I. Gralewicz-Wolny, B. Mytych-Forajter, Po pierwsze. O literaturze dla dzieci (i nie tylko), Kraków 2019 (np. rozdziały: Doktor Dolittle i jego zwierzęta Hugh Loftinga-lektura ekokrytyczna, „Tę ksiażkę wymyślit pies”. Ferdynand Wspaniały Ludwika Jerzego Kerna jako lektura ekokrytyczna); K. Starnawska, Agata jako „człowiek ekologiczny”. Lustro pana Grymsa Doroty Terakowskiej w lustrze ekokrytyki, [w:] Imaginautka zaangażowana. Twórczość i biografia Doroty Terakowskiej z perspektywy XXI wieku, red. K. Slany, K. Wądolny-Tatar, Kraków 2021 [w druku].

${ }^{9}$ Zob. M. Moskalewicz, „Murzynek Bambo - czarny, wesoty...”. Próba postkolonialnej interpretacji tekstu, „Teksty Drugie” 2005, nr 1-2, s. 259-270; M. Inglot, Murzynek Bambo Juliana Tuwima $w$ świetle krytyki postkolonialnej i feministycznej, [w:] ,Stare” $i$,nowe” $w$ literaturze dla dzieci i mtodzieży, red. B. Olszewska, E. Łucka-Zając, Opole 2010, s. 37-48; M. Tramer, Bambo zrobit swoje, „Acta Universitatis Lodziensis. Folia Litteraria Polonica” 2014, nr 4, s. 149-160; I. Gralewicz-Wolny, Pożegnanie Murzynka Bambo, [w:] Wyczytać 
czy podróżniczych ${ }^{10}$. Swoistą syntezę (post)kolonialnych wątków w piśmiennictwie dla młodzieży oraz szkolnych lekturach zaproponowała Barbara Tomalak, odnosząc się do W pustyni i w puszczy Sienkiewicza (mentalnego „kolonizatora”, jak nazwała go badaczka), cyklu powieściowego Alfreda Szklarskiego, wierszyka Tuwima i innych literackich przykładów. Autorka szkicu Postkolonializm w literaturze młodzieżowej podjęła dyskusję ze stereotypami dzikości i pierwotności Afryki, niższości kultury mieszkańców tego kontynentu, przypisanym im lenistwem, kanibalizmem, z ich animalizacja w XIX- i XX-wiecznej literaturze polskiej oraz antroponimem: Murzyn ${ }^{11}$.

$\mathrm{W}$ badania postkolonialne i postzależnościowe zawsze wpisany jest więc horyzont przeszłości i/lub przyszłości. Dotyczy to także innych przeformułowań badawczych, za którymi idzie zmiana paradygmatu naukowego, np. z antropocentryzmu na antropocen. Przesunięcia te pozwalają też czytać literaturę dla małych i młodych odbiorców - inaczej, na nowo. Wydaje się jednak, że w związku ze wspomnianym horyzontem temporalnym można tu jednak mówić o dwóch kierunkach czytania, które umownie nazwiemy retencyjny i protencyjny. Ten pierwszy zasadza się na sposobach odczytywania historii i jej reprezentowania w literaturze dla dzieci i młodzieży. Drugi zdaje się mieć charakter interwencyjny, w pełni środowiskowy. Pierwszy bardziej wiąże młodego odbiorcę z przeszłością, drugi „wplata” go w przyszłość, a nawet sugeruje zakres działań. Oba mają charakter ratowniczy w odniesieniu do tego „skąd przychodzimy” i „dokąd zmierzamy”. Nie sa to więc całkowicie rozdzielne tryby narracji. Bywają mocno splecione, by wskazać chociaż na prozę Joanny Rudniańskiej (Kotka Brygidy) czy Ryszarda Marka Grońskiego (Szlemiel), w których to utworach istotne znaczenie ma udział zwierząt w fabularnych reprezentacjach tematyki Zagłady, uwzględniających współobecność „braci mniejszych”, a nawet ich punkt widzenia $\mathrm{w}$ zoonarracjach ${ }^{12}$. Z kolei interferencje historiografii i świadectwa drzew odnajdujemy w powieści Cezarego Harasimowicza Mirabelka, w której pisarz literacko spożytkował rzeczywiste zdarzenia ${ }^{13}$ (w tym historię własnej

świat-międzykulturowość w literaturze dla dzieci i młodzieży, red. B. Niesporek-Szamburska, M. Wójcik-Dudek, współpraca A. Zok-Smoła, Katowice 2014, s. 95-104.

${ }^{10}$ Zob. M. Żółkoś, Łowcy kultur. Cykl powieściowy o Tomku Wilmowskim w świetle myśli postkolonialnej, [w:] Studia postkolonialne nad kulturq i cywilizacja polska, red. K. Stępnik, D. Trześniowski, Lublin 2010, s. 347-358.

${ }^{11}$ Zob. B. Tomalak, Postkolonializm w literaturze młodziė̇owej, czyli... mamy problem!, „Świat i Słowo” 2017, nr 2, s. 87-103.

${ }_{12}$ Zob. A. Jarzyna, Szlemiele. Zwierzęta wobec Zagłady w literaturze dla dzieci, „Narracje o Zagładzie" 2016, nr 2, s. 235-256.

${ }^{13}$ Zob. M. Smykowski, Ekologiczne świadectwo Zagtady. Repatriacja mirabelki na Muranów, [w:] Świadek: jak się staje, czym jest?, red. A. Dauksza, K. Koprowska, Warszawa 2019, s. 278-291. 
rodziny), związane z nie-ludzką figurą rośliny-świadka na warszawskim Muranowie. W utworze Harasimowicza narratorem jest niewielkie drzewo owocowe, rosnące na jednym z warszawskich podwórek, opowiadające wojenną historię najbliższej okolicy i rodzin w niej mieszkających. Ludzka pokoleniowość łączy się tutaj z kolejnymi generacjami drzew. W kontekście biopoetyki i studiów nad pamięcią pisze o tej powieści Agnieszka Kwiatkowska:

Zasada świata jest przemijanie, kolejni bohaterowie opowieści odchodzą w niepamięć, ale na kartach historii pojawiają się nowi, którzy w pewnym sensie powtarzają dawne biografie - kochaja, zakładają rodziny, budują międzyludzkie relacje. Życie trwa z niesłabnącą moca, miłość łączy kolejne pary, a małe dziewczynki wciąż przytulają się do pnia mirabelki, aby usłyszeć głosy przeszłości budujące współczesną historię. Aby to było możliwe, potrzebny jest jednak świadomy, ludzki gest przywracający pamięć - ręka, która posadzi mirabelkę, nada jej znaczenie i da schronienie widmom pragnącym odwiedzić swój dawny dom ${ }^{14}$.

W refleksji nad lektura małego i młodego czytelnika trzeba widzieć możliwości odczytania utworów, jakie oferuje się w systemie edukacji zbiorowej oraz $\mathrm{w}$ przestrzeni domu rodzinnego. W warunkach prawidłowego funkcjonowania ta druga sfera niezmiennie silniej motywuje do doświadczeń czytelniczych. Społeczno-środowiskowe funkcje literatury sa jednak uzasadnialne w obu sytuacjach - szkolnego i pozaszkolnego kontaktu z dziełem literackim (bo przecież nie tylko z książką jako medium) i innymi tekstami kultury, czy zdarzeniami kultury ${ }^{15}$. W poniższych rozważaniach interesuje nas jednak odbiór dzieła literackiego jako efekt indywidualnego wyboru, który skądinąd zawsze może spleść się z działaniami dydaktycznymi. A nawet bardziej jeszcze zajmuje nas tutaj możliwość odczytania pozaszkolnych dzieł literackich, adresowanych do młodego odbiorcy, lokowanych w kontekście kulturowej teorii literatury, widzianych przez pryzmat splotu nowoczesnych tendencji literaturoznawczych.

Zapoznawanie młodego pokolenia z przeszłościa jest zawsze dialogowaniem z nią - z powodu zmienności metodologii i sposobów odczytań utworów literackich, nieprzezroczystości i nieneutralności narracji o minionych

${ }^{14}$ A. Kwiatkowska, Korzenie pamięci. O Mirabelce Cezarego Harasimowicza, „Paidia i Literatura” 2020, nr 2, s. 75. W kontekście „splatania” i teorii aktora-sieci B. Latoura pisze o Mirabelce M. Cyzman, Historia jednego drzewka. O Mirabelce Cezarego Harasimowicza z perspektywy ,zwrotu ku rzeczom” [maszynopis udostępniony przez autorkę, przeznaczony do publikacji w jednym z czasopism naukowych].

${ }^{15}$ Sposoby odczytania w szkole proponują autorki artykułów zamieszczonych w „Polonistyce. Innowacjach”: A. Jarzyna, O czym myślę, kiedy myślę o zwierzętach w edukacji polonistycznej? Siedem odpowiedzi, „Polonistyka. Innowacje” 2020, nr 11, s. 63-76; M. Ochwat, (Wspót)myślenie w humanistyce. Literackie ekokształtowanie w epoce antropocenu, „Polonistyka. Innowacje” 2020, nr 12, s. 31-52. 
zdarzeniach, funkcji konstrukcji (opartych na wyobraźni) i rekonstrukcji (opartych na pamięci) osób, miejsc, sytuacji w opowieści o przeszłości, subiektywizacji przekazu, tylko dążącego do obiektywizmu, językowej strukturyzacji opowieści z respektowaniem jego reguł systemowo-komunikacyjnych, a więc także stosowaniem poetyk historiograficznych. Na te i inne aspekty wskazywał w swoich pracach Hayden White ${ }^{16}$. Tytuły monografii uczonego stanowią skrócone wykładnie jego tez: Proza historyczna, Poetyka pisarstwa historycznego, Przeszłość praktyczna. Opisanym przez badacza strategiom narracyjnym fabularyzacji, argumentacji, ideologizacji i przekształceniom tropologicznym, ze względu na użycie metafor, metonimii, synekdoch, ironii, podlega również pisarstwo dla dzieci i młodzieży ${ }^{17}$. Na przykład historię przedstawiona jako romans, w ramach strategii fabularyzacji, odnajdujemy w powieści Kaliny Jerzykowskiej Dwórki królowej Bony. Na straży miłości, będącej swoista „odpowiedzią" na dawną prozę dla młodzieży: Paziów króla Zygmunta Antoniny Domańskiej ${ }^{18}$. Nie bez znaczenia jest tu kontekst płci, zwłaszcza rozumianej jako społeczno-kulturowy konstrukt, decydujący o możliwym opisie tych powieści w ramach studiów nad dziewczęcością (girlhood studies) czy chłopięcością (boyhood studies) ${ }^{19}$. Z kolei historia w aspekcie komediowym została pokazana w fikcji o znamionach groteski w cyklu parahistorycznym Ale historia... autorstwa Grażyny Bąkiewicz. Autorka zdecydowała się na przedstawianie wybranych wydarzeń z przeszłości jako zbiegu okoliczności, sensacji, z efektami przemieszczania w czasie uczniów jednej z klas za sprawą nauczyciela historii. Ponadto strategię narracyjną wymownie podkreślają tytuły poszczególnych części, np.: Mieszko, ty wikingu! - jako nawiązanie do historycznych dywagacji na temat rodowodu piastowskiego księcia, późniejszych koneksji rodzinnych, a także pewnej „dzikości” obyczajów władcy; Kazimierzu, skqd ta forsa? - jako refleksja na temat ekonomicznej sytuacji państwa i jego rozwoju gospodarczego za czasów Kazimierza Wielkiego, a nawet aluzja do inwestycji króla, przemieniającego Polskę z drewnianej w murowana; Zygmuncie, i kto tu rzqdzi? - jako

${ }^{16} \mathrm{Na}$ oddziaływanie teorii White'a na humanistykę i recepcję jego dzieł w Polsce wskazuja prace: J. Muchowski, Polityka pisarstwa historycznego. Refleksja teoretyczna Haydena White'a, Toruń 2015; Hayden White w Polsce. Fakty, krytyka, recepcja, red. E. Domańska, E. Skibiński, P. Stróżyk, Kraków 2019.

${ }^{17}$ Zwracała na to uwagę w obszernej monografii G. Skotnicka, Barwy przeszłości. O powieściach historycznych dla dzieci i młodzieży 1939-1989, Gdańsk 2008.

${ }^{18}$ Próbę nowego odczytania twórczości autorki Historii żóttej ciżemki przyniosła zbiorowa monografia (Re)konstrukcje przeszłości w prozie Antoniny Domańskiej, red. M. Chrobak, K. Wądolny-Tatar, Kraków 2019.

${ }^{19}$ W Polsce od lat takie badania prowadzi Grażyna Lasoń-Kochańska. Zob. tejże, Gender w literaturze dla dzieci i młodzieży. Wzorce ptciowe i kobiecy repertuar topiczny, Słupsk 2012, a także liczne studia tej autorki w monografiach zbiorowych i czasopismach. 
namysł nad sposobami rządzenia, udziałem szlachty, ale również kobiet (w tym królowej Bony jako żony i matki), w zarządzaniu państwem. Przede wszystkim groteskowo-apofatyczny wymiar reprezentacji przeszłości wzmacniają komiksowe sekwencje, towarzyszące tekstowi literackiemu, odnoszące się do wybranych składowych życia społecznego z humorystycznym przebiegiem zdarzeń albo będące próbą zarysowego i umownego przedstawienia elementów stroju czy rodzajów stosowanej broni. Komiks historiograficzny dla dzieci mógłby zresztą stanowić osobny przedmiot badańn ${ }^{20}$.

Wspomniany wcześniej dyskurs postkolonialny nie jest ahistoryczny, podlega również „upolitycznieniu”, które wynika z hegemonii historycznej, supremacyjnej polityki mocarstw, ekonomii wyzysku, a skutkuje m.in. skomplikowaniem tożsamości zbiorowych, narracjami melancholijnymi czy legitymizującymi miejsca lub obszary (np. sentymentalizacja Kresów ${ }^{21}$, literackie uprawomocnienie tzw. Ziem Odzyskanych ${ }^{22}$ ). Dominująca funkcją literatury staje się wówczas kompensacja, z wpisaną w nią dychotomią: polskość - niepolskość.

$\mathrm{Na}$ tle dziejowości ujawniają się głównie antropocentryczne tematy: biograficzny, postpamięciowy, migracyjny. Ale na temporalnym wymiarze opierają się też refleksje posthumanistyczne jako studia nad rzeczami, zwierzętami, roślinami, nierzadko w połączeniu z wymienionymi wcześniej. Z jednej strony eliminacja ludzkiej perspektywy nie jest (całkowicie) możliwa, z drugiej - podkreśla się nieautonomiczność ludzkiej egzystencji. Przekonuje o tym Przemysław Czapliński w innym swoim szkicu:

[...] z jednej strony nowoczesna maszyna antropologiczna pracuje wytrwale nad oddzieleniem człowieka od całej reszty istnień, z drugiej ta sama maszyna antropologiczna, ulepszając człowieka, odsłania jego nieoddzielną przynależność do reszty. Aktywność separacyjna wiąże się z prawem, nauka, konsumpcja, i potrzebuje definicji, łączenie natomiast usiłuje podważyć dyskursy, więc mnoży właściwości. Obezwładnienie siły prawa jest możliwe na moment, kiedy to jednak się udaje,

${ }^{20}$ Przedmiotem oglądu mogłaby być seria Wojenna odyseja Antka Srebrnego 1939-1944, Warszawa 2015-2019. Autorami scenariuszy i tekstów w poszczególnych tomach sa: T. Robaczewski, G. Drojewski, M. Konarski, autorem rysunków: H. Ronek. Natomiast komiksowa panoramę władców Polski stworzyły M. Strękowska-Zaremba, J. Zagner-Kołat, Królewskie życie królów, Łódź 2019.

${ }^{21}$ Zob. D. Skórczewski, Melancholia dyskursu kresoznawczego, [w:] tegoż, Teoria - literatura - dyskurs. Pejzaż postkolonialny, Lublin 2013, s. 427-473. Fantazmatyczność doświadczenia kresowego w literaturze zbadał również M. Dąbrowski, Kresy w perspektywie krytyki postkolonialnej, „Porównania” 2008, nr 5, s. 91-111.

${ }^{22}$ Wyczerpująco omawiają ten problem prace: K. Gieba, Lubuska literatura osadnicza jako narracja założycielska regionu, Kraków 2018; K. Siewior, Osadzanie. O dyskursie Ziem Odzyskanych, [w:] tejże, Wielkie poruszenie. Pojałtańskie narracje migracyjne $w$ kulturze polskiej, Warszawa 2018, s. 64-94. 
powstaje chwilowa strefa nieodróżnialności. W strefie tej człowiek nie jest autonomiczny, bo należy do hybrydycznych kolektywów bytowych, poskładanych z ludzi, zwierząt i maszyn. W strefie tej człowiek nie jest homogeniczny, bo jego ciało nie stawia oporu przed (metalowymi, zwierzęcymi czy elektronicznymi) intruzami z zewnątrz. W strefie tej człowiek nie może w języku wypowiedzieć swojej zakłóconej tożsamości $[\ldots]^{23}$.

Owa (nie)odróżnialność, jako podstawa biopoetyki, przyjmującej status refleksji teoretycznej nadrzędnej wobec antropocentryzmu i nie/post/antropocentryzmu, jest kategorią (przynajmniej) dwoista jeśli nie wieloraka. Człowiek nie jest w stanie umieścić metodologii, które stosuje, poza biologia i historia. Narracje historiograficzne dla dzieci i młodzieży również dzieją się na styku biologii i historii, eksponują dziecięcość, płciowość, dojrzewanie bohaterów w czasie, ponadto historia wojny to zawsze historia ciała (higieny, chorób, kalectw, bólu, ran, blizn, śmierci) ${ }^{24}$. Takie przeświadczenie warunkuje łączliwość problematyki historyczności, cielesności i innych, nierozdzielalność tego, co ludzkie i nie-ludzkie. Z tego powodu w polskiej literaturze dla dzieci i młodzieży XXI wieku obserwowalne są interferencje wymienionych wcześniej nurtów, sytuowanych na tle wiedzy o przeszłości: biograficznego, postpamięciowego, migracyjnego, postzależnościowego i posthumanistycznego w jego podstawowych przejawach. Dodatkowo konwencje baśni, legendy czy mitu, przy wsparciu realizmu magicznego albo formuły „świata na opak”, stosowanych w utworach dla małych i młodych odbiorców, zdają się eliminować, a przynajmniej osłabiać kontrast typologiczny światów: ludzkiego i nie/poza/post/ludzkiego.

Literacka historiografia dla dzieci i młodzieży w XXI wieku wypracowuje sposoby komunikacji z młodym czytelnikiem, poszukuje atrakcyjnych i nośnych form przekazu, łaczacych wiedzę, pamięć, wyobrażenia o przeszłości z innymi obszarami ludzkiej i nie tylko ludzkiej aktywności. Splatanie z przeszłością realizowane jest przez różne zjawiska literacko-wydawnicze: (1) stematyzowane serie wydawnicze, (2) cykle genealogiczne i genologiczne, (3) zbeletryzowane biografie, (4) osobne utwory przywołujące rodowód państwa polskiego i linie dynastyczne, (5) postpamięciowe narracje tzw. „drugiego pokolenia”, (6) utwory podejmujace problematykę migracji jako aktualnego problemu, wynikającego jednak z przesłanek historyczno-politycznych.

${ }^{23}$ P. Czapliński, Literatura i życie. Perspektywy biopoetyki, [w:] Teoria-literatura-ízycie. Praktykowanie teorii w humanistyce wspótczesnej, red. A. Legeżyńska, R. Nycz, Warszawa 2012, s. 93.

${ }^{24}$ Przekonująco pisze o tym M. Wróblewski, również w perspektywie biopolityki. Zob. tegoż, Doświadczenie dzieciństwa. Studium z antropologii literatury, Toruń 2019, szczególnie podrozdziały: Ciało dzieciństwa na wojnie. W strone fikcji oraz Ciało dziecinstwa na wojnie. W stronę dokumentu. 
Nie wszystkie wymienione formalno-problemowe realizacje tekstowe zostaną niżej szerzej omówione. Poprzestaniemy na zasygnalizowaniu niektórych z nich ze względu na materiałową obszerność publikacji historiograficznych dla dzieci i młodzieży oraz z uwagi na istnienie prac naukowych opisujących niektóre z wyszczególnionych tu zagadnień. Wyznaczenie ich ma zreszta charakter umowny i otwarty, dla przykładu - stematyzowana seria wydawnicza Wojny dorostych - historie dzieci, wydawana od kilku lat przez jedna $\mathrm{z}$ łódzkich oficyn, jest jednocześnie sposobem praktykowania postpamięci ${ }^{25}$, ufundowanej na migracyjnych aspektach rzeczywistości czy biografiach. Istnieją jednak również powody, dla których warto potraktować te przejawy aktywności autorsko-wydawniczej jako osobne kategorie czy zjawiska, i to właśnie - zgodnie z ich wyliczeniem - jako (bardziej) formalne i (bardziej) problemowe. W strukturze wszystkich utworów obserwowalny jest splot czynników, które mogłyby być rozpatrywane z punktu widzenia osobnych zwrotów i tendencji (np. biograficznego, migracyjnego, postzależnościowego, posthumanistycznego i innych). Nie zawsze jednak wskazanie dominanty konstrukcyjno-semantycznej, na tle pozostałych synchronicznie dostępnych możliwości analityczno-interpretacyjnych, jest potrzebne i literaturoznawczo przydatne. Powyższe wyliczenie literacko-wydawniczych projektów wyznacza porządek dalszego oglądu.

Wyróżnikiem serii Wojny dorostych - historie dzieci pozostaje temat wskazujący na doświadczenie dzieciństwa zależne od świata dorosłych, z pełnym udziałem najmłodszych w dramatach konfliktów zbrojnych i ich skutkach. Każdy z kilkudziesięciu utworów autorstwa znanych polskich twórców dla młodego pokolenia powstał na kanwie przebiegu czyjegoś życia - sa narracjami z autopsji albo opowieściami na podstawie danych od informatorów-świadków, realizują różne wzorce biografii jako gatunku, a zatem dotyczy ich dynamika świadczenia, która sprawia, że:

[...] właściwie każdy świadek, przekazując swoje świadectwo, występuje w kilku funkcjach jednocześnie: jako poszkodowany - choćby przez to, czego nie da się od-zobaczyć i od-doświadczyć, zaświadczający o krzywdzie tych, którzy nie przeżyli lub nie są w stanie świadczyć, jako dostarczyciel dowodów, jako oskarżyciel, jako podejrzany o (współ)sprawstwo itd. ${ }^{26}$

${ }^{25}$ Kwestiom tym poświęciła monografię M. Wójcik-Dudek, W(y)czytać Zagtadę. Praktyki postpamięci w polskiej literaturze XXI wieku dla dzieci i młodzieży, Katowice 2016. Autorka uwzględniła w oglądzie naukowym utwory, które ukazały się do momentu druku monografii. Po 2016 roku a do końca 2020 seria powiększyła się o kilkanaście publikacji. Problematyką Zagłady w literaturze dla dzieci zają się również K. Rybak, Dzieciństwo w labiryncie getta. Recepcja mitu labiryntu w polskiej literaturze dziecięcej o Zagtadzie, Warszawa 2019.

${ }^{26}$ A. Dauksza, Ustanawianie świadka, [w:] Świadek: jak się staje, kim jest?, red. A. Dauksza, K. Koprowska, Warszawa 2019, s. 171. 
Do narracji autobiograficznych należy proza Joanny Papuzińskiej (m.in. Asiunia), Ireny Landau (Ostatnie piętro), Andrzeja Perepeczki (Jędruś, chtopak ze Lwowa, w której to powieści rodowód rodziny i identyfikacja tożsamościowo-topograficzna opiera się na łączności z miejscem utraconym). Dwie pierwsze narracje wpisuja dzieciństwo postaci w przestrzeń Warszawy. Zdecydowaną większość stanowią jednak opowieści odnoszące się do cudzego życia, autentyczność wielu ludzkich istnień poświadczają paratekstowe komentarze i fotografie stanowiące uzupełnienia, suplementujące narrację główną. Mogą być one rozpatrywane jako składowe (nie)uwiarygodnienia, na które zwraca uwagę Tomasz Majewski, recenzent zbiorowej monografii Świadek: jak się staje, kim jest?, który pisze: „Obecnie już nie antyteza mówienia i języka jest, jak się wydaje, kluczowa u świadka (jako nie-ludzkiego i postludzkiego), ale naruszanie przez świadectwo uzgodnionych kolektywnych reguł prawdo-mówności" ${ }^{27}$. Wspomniane reguły prawdo-mówności mogą wynikać z antynomii jawne - ukryte, niezabronione - zabronione, niecenzurowane - cenzurowane w politycznym zarządzaniu przeszłością i społeczną wiedzą o niej (za Michelem Foucaultem można powiedzieć, że władza i w tym aspekcie zawsze wytwarza wiedzę, a każdy podmiot jest funkcja ich obu). Natomiast w literaturze dla dzieci wewnatrztekstowy aspekt komunikacyjny obejmuje jeszcze fabularnie „zmowę” milczenia dorosłych, by oszczędzić małym bohaterom cierpień, lęków i frustracji, utrzymywać ich w nieświadomości, a pozafabularnie wynika ze swoistego autorskiego „paktu o nieagresji”, zawartego z potencjalnym adresatem serii, dzieckiem w wieku 9-12 lat, paktu zakładającego nieepatowanie okrucieństwem przy niefałszowaniu rzeczywistości historycznej.

Wszyscy mali bohaterowie prozy Pawła Beręsewicza, Doroty Combrzyńskiej-Nogali, Renaty Piątkowskiej, Michała Rusinka, Katarzyny Ryrych, Kazimierza Szymeczki i innych stają wobec problemów komunikacyjnych, dotyczacych kwalifikacji słowa i czynu jako prawdy i kłamstwa, (nie)dotrzymanej tajemnicy, przysięgi, powierzonej korespondencji. W Zaklęciu na , $w$ " Rusinka, w którym opisano dziecięce losy Włodzimierza Dusiewicza, polskiego reżysera i scenarzysty, bohater nieświadomy zadań, jakie wykonywał, powie później, odwołując się również do doświadczeń dziecka XXI wieku: „[...] dobrze, że nic nie wiedziałem. Rozwoziłem je [powstańcze rozkazy przyp. K.W.-T.] i już. Nie było wtedy esemesów (wyobrażacie sobie?), nie było maili. Byłem za to ja i mój dziecinny rowerek" ${ }^{28}$. Wskazanie na wiek postaci mówiącej nie jest tu jednoznaczne, podobnie jak w prozie Renaty Piątkowskiej, chociaż w jej powieści zachodzi wyraźne wyprowadzenie dorosłego

${ }^{27}$ T. Majewski, z recenzji wydawniczej, [w:] Świadek: jak się staje, kim jest?, red. A. Dauksza, K. Koprowska, Warszawa 2019, IV strona okładki.

${ }^{28}$ M. Rusinek, Zaklęcie na „w”, il. J. Rusinek, Łódź 2011, s. 5. 
opowiadającego wydarzenia z własnego dzieciństwa, a utwór zyskuje ramy kompozycji szkatułkowej: „Pan Szymon Bauman zamilkł i wydawało się, że już nic więcej nie powie. Jednak po chwili wrócił do przerwanego wątku”29. W narracji pada zatem nazwisko mężczyzny, którego lata dziecięce zostały tutaj przedstawione, a jego życie i przeżycie czasu II wojny światowej łączy się z osobą Ireny Sendlerowej, również bohaterki Wszystkich moich mam ${ }^{30}$. Tytuł jednoznacznie wskazuje na konieczność zmiany miejsca podopiecznych pielęgniarki i działaczki społecznej, obecność „kolejnych mam” w życiu uratowanych żydowskich dzieci, a w fabule zmiana pobytu zachodziła często $\mathrm{z}$ uwagi na aspekty komunikacyjne - m.in. niefortunną wypowiedź dziecka w grupie niewtajemniczonych osób albo kontakt z niewłaściwa, z uwagi na niebezpieczeństwo ujawnienia niektórych przedsięwzięć, osobą. Taka sytuacja została opisana też w Małej wojnie Katarzyny Ryrych. W powieści zirytowany nauczyciel muzyki zwraca się do swojej uczennicy, która odkryła miejsce schronienia żydowskiego chłopca: „Myślałem, że zrozumiałaś, by się tutaj nie kręcić. Lekcja i do domu. Ale nie, nie spoczęłaś, dopóki nie dopięłaś swego. Dowiedziałaś się czegoś, czego wiedzieć nie powinnaś. Teraz ty także jesteś w niebezpieczeństwie. Jeżeli nie wiesz, czym grozi ukrywanie ludzi... Wojna to nie zabawa"31. Babcia dziewczynki, bioraca udział w działaniach ratujących życie innych, dodaje: „Takie bywają skutki nadmiernej ciekawości. Uriasz opuści dzisiaj dom pana Stefana, podobnie Cyrla, Sara i Ryfka. Wszyscy, których udało mu się ocalić”32.

Jeszcze inna sytuacja wpływu słowa na rzeczywistość, oparta na społeczno-komunikacyjnym potencjale mitów, została przedstawiona w Bezsenności Jutki Doroty Combrzyńskiej-Nogali. Mitologia basenu śródziemnomorskiego nie tylko stanowi rezerwuar opowieści akulturacyjnych, staje się również zbiorem narracji kompensacyjnych, przekładających się na scenariusze dziecięcych zachowań, np. związanych z zabawą w chowanego w przestrzeni getta i w poszczególnych kamienicach. Mała Jutka, wyposażona przez dziadka w kłębek wełny, niczym Ariadna oczekuje w swojej kryjówce na jego powrót, pamiętając o słowach, które wypowiedział: „Wiem, że jest ciemno, ale przypomnij sobie Tezeusza, jak przetrwał w labiryncie. Tak samo w ciemnościach. W dodatku czyhał na niego Minotaur. A tu potwór jest na zewnątrz. Prawda?" ${ }^{33}$. W fabule prozy Combrzyńskiej-Nogali Jutka przetrwała Wielką Szperę w Łodzi, a jej postać jest reprezentacją zbiorowego

${ }^{29}$ R. Piątkowska, Wszystkie moje mamy, il. M. Szymanowicz, wyd. 2, Łódź 2014, s. 20.

${ }^{30}$ Zob. także A. Czerwińska-Rydel, Listy w butelce. Opowieść o Irenie Sendlerowej, wyd. 3, Łódź 2018.

${ }^{31}$ K. Ryrych, Mała wojna, Łódź 2019, s. 70.

${ }^{32}$ Tamże.

${ }^{33}$ D. Combrzyńska-Nogala, Bezsenność Jutki, il. J. Rusinek, wyd. 2, Łódź 2011, s. 71. 
portretu dzieci, które doświadczyły życia w getcie ${ }^{34}$. Krystyna Pietrych pisze o adresatywności prozy Combrzyńskiej-Nogali, która posługuje się „,...] elementami fantastycznymi, przesłania drastyczności, opowiada o niemal niemożliwej przyjaźni z dziewczynką po drugiej stronie muru, o dobrym Niemcu, który nie zastrzeli małej właścicielki kota w koszyczku [...]. Paradoksalnie jednak nie zostaje tutaj zerwany pakt referencyjny, bowiem wszystkie te zabiegi mają służyć wydobyciu - nie przesłonięciu - prawdziwych wydarzeń i prawdziwej przestrzeni. Podkreślają to także fotografie i krótka informacja o Litzmannstadt Ghetto umieszczona na końcu książki”35. Właśnie te paratekstualia towarzyszace każdemu tekstowi głównemu, powstałemu w ramach serii, poświadczają autentyczność wydarzeń w ich przestrzennym, czasowym, a przede wszystkim personalnym wymiarze. Seria jako polilog zdaje się potwierdzać, że „[...] świadectwo nigdy nie wydarza się w całkowitym odosobnieniu, nie jest też spektaklem jednostkowości; to raczej splot aktantów, dynamiczna relacja, akt przepływu energii i afektów między jednostkami o różnych motywacjach, pragnieniach, celach i scenariuszach zachowań emocjonalnych" ${ }^{36}$.

Efekt serii, z jej literacko-graficzna koncepcja, semantyczno-kompozycyjną spójnościa, warunkowaną odniesieniami do wyznaczonego przez dramaty wojen XX i XXI wieku (najczęściej II wojny światowej) spektrum spraw związanych z dzieciństwem, rodzina, domem, trwałą lub chwilową utrata bliskich, poczuciem bezpieczeństwa, w odbiorze czytelniczym przekłada się na potrzebę posiadania kolekcji dzieł literackich. Ich komplet daje w pewnym stopniu iluzję pełnego obrazu przeszłości, przynajmniej z jakiejś perspektywy. Tym bardziej, że seria rozpięta jest na szerokim horyzoncie historycznym, jak dotychczas: od plebiscytów i powstań na Górnym Śląsku po I wojnie światowej (Gołabek niepokoju Kazimierza Szymeczki) po rzeczywistość stanu wojennego w Polsce ${ }^{37}$ (Wilczek Katarzyny Ryrych, nawiązujący

${ }^{34} \mathrm{O}$ egzystencji najmłodszych w warszawskim i łódzkim getcie, m.in. utrwalonej na fotografiach, pisze. J. Leociak, Dzieci Holokaustu: awers i rewers, [w:] tegoż, Doświadczenia graniczne. Studia o dwudziestowiecznych formach reprezentacji, wyd. 2 popr., Warszawa 2018, s. 246-267.

${ }^{35} \mathrm{~K}$. Pietrych, (Re)prezentacje czy symulacje? Przestrzeń tódzkiego getta w literaturze XXI wieku, [w:] Geograficzne przestrzenie utekstowione, red. B. Karwowska, E. Konończuk, E. Sidoruk, E. Wampuszyc, Białystok 2017, s. 328. Na reprezentacje historii, werbalną i wizualną powściagliwość, niedopowiedzenia, rolę ilustracji w utworze Combrzyńskiej-Nogali zwraca też uwagę H. Dymel-Trzebiatowska, Opowieść dla dzieci a opowieść dla dorostych. Dwie literackie odstony Wielkiej Szpery w tódzkim getcie, [w:] (Od)pamiętywanie-gry z przeszłościq w literaturze dla dzieci i młodzieży, red. B. Niesporek-Szamburska, M. Wójcik-Dudek, Katowice 2018, s. 173-186.

${ }^{36}$ A. Dauksza, Ustanawianie świadka..., s. 196.

${ }^{37}$ Okres stanu wojennego przybliżył młodemu pokoleniu w swojej baśni magicznej Jacek Dukaj. O modelu fikcji zastosowanym przez pisarza we Wrońcu pisze M. Kobielska, Polska 
odzwierzęcym antroponimem w nagłówku do Obławy Jacka Kaczmarskiego; Zbuntowane słowa Joanny Papuzińskiej).

Za cykl genealogiczny i genologiczny zarazem możemy uznać opowiadania trojga autorów: Grażyny Bąkiewicz, Kazimierza Szymeczki i Pawła Wakuły. Tożsamość twórców i genologiczna deklaracja w tytułach utworów decydują o jednolitych kwalifikacjach gatunkowych poszczególnych pięciu tomów: Piastowskie orty. 10 opowiadań z czasów Piastów; Od morza do morza. 10 opowiadań z czasów Jagiellonów; Husarskie skrzydta. 10 opowiadań z czasów Rzeczpospolitej szlacheckiej; Walka o wolność. 10 opowiadań z czasów rozbiorów; Odzyskana niepodległość. 10 opowiadań z XX wieku. Natomiast sięganie do korzeni państwa polskiego i próba wyprowadzenia z przeszłości reguł dziejowości i państwowości, jak również utworzenie panoramy polskiej historii od czasów najdawniejszych po rok 1989, powoduja, że można odczytywać cykle tych opowiadań, powstałe także w ramach serii Zdarzyło się $w$ Polsce, $\mathrm{w}$ aspekcie genealogicznym.

Krystyna Jakowska, ustalając zakresy spójności cyklu opowiadań, pisała:

Zewnętrznymi wyznacznikami cyklu są dla nas powiązania dwojakiego rodzaju: na poziomie świata przedstawionego i na poziomie „tekstu”. Te pierwsze to związki czasu, przestrzeni, bohaterów i zdarzeń poszczególnych opowiadań. Nie zawsze semantycznie istotne, a zatem nie zawsze „cyklotwórcze” - za to łatwo uchwytne. Te drugie, „tekstowe” i metatekstowe, to scalające tytuły, motta, początki, końce, słowem cała „delimitacja” cyklu oraz linearne uporządkowanie opowiadań. Są one prawie zawsze istotne, znaczące ${ }^{38}$.

$\mathrm{Na}$ wspomnianą delimitację interesującego nas tutaj cyklu wpływają również nagłówki opowiadań składowych, precyzyjniej lokujące wydarzenia w czasie za pomoca formuły: „opowieść z czasów...”, a także umieszczone na ostatnich stronach cyklu-książki noty historyczne zawierające biogramy, wyjaśnienia, definicje pojęć. Spójność cyklu jako projektu artystycznego zapewnia jego graficzne opracowanie przez Mikołaja Kamlera, z ilustracjami respektującymi realia epok, osią czasu jako motywem graficznym, jednolitym „tekstem” okładek pięciu tomów, nawiązującym do metaforycznej konceptualizacji dziejów jako teatru. Na każdym z okładkowych przedstawień widnieje inna postać, wychylająca się jakby zza kulis historii na scenę współczesności, jednocześnie odchylając kurtynę dziejów.

Zewnętrzne i wewnętrzne wyznaczniki - te drugie bardziej wynikające z semantyki narracji i odnoszące się do cech trybu opowiadania, w tym do

kultura pamięci $w$ XXI wieku: dominanty. Zbrodnia katyńska, powstanie warszawskie $i$ stan wojenny, Warszawa 2016.

${ }^{38} \mathrm{~K}$. Jakowska, O cyklu opowiadań. $Z$ teorii $i$ historii cyklu narracyjnego $w$ Polsce, Białystok 2011, s. 13. 
symetryczności, gradacyjności, antytetyczności układu zdarzeń - wpływają na relatywnie jednoznaczne kwalifikacje cyklu opowiadań, rozważanego ze względu na realizacje gatunkowe i właściwości kompozycji. Z pewnością ważną cecha, wynikającą zarówno z założeń genologicznych, jak i kompozycyjnych, jest przebieg zdarzeń w opowiadaniach autorstwa Bakiewicz, Szymeczki i Wakuły, zmierzający do - jeśli nie szczęśliwego, to przynajmniej korzystnego dla młodego bohatera - finału, z niedaremnością jego działań i poświęceń. Jest to również rezultat ścisłej adresatywności i celowości wypowiedzi literackiej dla młodego odbiorcy. Aktorzy cyklów starają się zachować narracyjny „parytet”, narratorami i bohaterami opowiadań bywaja dziewczęta i chłopcy. Kazimierza Wielkiego ratuje z opresji mały kłusownik Mikołaj zwany Zadra, któremu król potem darowuje przewinienia, uparty, sprytny - i jak czytamy w opowiadaniu - hardy. Zaś o czasach panowania nastoletniej Jadwigi Andegaweńskiej opowiada Leosia - rezolutna rówieśnica władczyni, dama jej dworu i hafciarka, uwieczniająca wydarzenia igła na płótnie, właściwie wykonująca specyficzną obrazkową kronikę. Cykle trojga autorów stanowiłyby kontaminację opowiadań typu portretowego i związanego z wydarzeniami historycznymi, które to kategorie opisuje Krystyna Jakowska w swojej monografii. Wraz z tymi dominującymi ujęciami splot narracyjny tworza elementy innych wymienionych przez badaczkę typów opowiadań: (auto)biograficzne, filozoficzne, religijne, intertekstualne.

$\mathrm{W}$ splataniu z przeszłością uczestniczą również narracje biograficzne, poddane beletryzacji, wpisane w doświadczenia współczesnego odbiorcy. Autorką wielu takich utworów jest Anna Czerwińska-Rydel. Pisarka eksploruje bieg życia znanych osób - naukowców i myślicieli (np. Alberta Einsteina, Jana Heweliusza, Artura Schopenhauera, Marii Skłodowskiej-Curie, Mikołaja Kopernika), muzyków (m.in. Fryderyka Chopina, Witolda Lutosławskiego, Henryka Wieniawskiego), literatów (Aleksandra Fredry, Józefa Ignacego Kraszewskiego, Henryka Sienkiewicza, Kornela Makuszyńskiego i innych). Tworzy wzory biograficzne determinowane momentami zwrotnymi, wyróżnionymi okresami życia i/lub jego finałem. Przykładem biografii modelowanej przez śmierć, enigmatycznie przedstawiona w utworze, jest Po drugiej stronie okna. Opowieść o Januszu Korczaku. Tytułowe okno jest tutaj symbolicznym komponentem przestrzeni, wyznaczajacym granice wnętrza i zewnętrza osób, światów, a także życia i śmierci, zwłaszcza gdy na koniec staje się okienkiem wagonu pociagu zmierzajacego do Auschwitz, przez które transportowane dzieci i ich opiekun usiłuja zaczerpnąć powietrza. Po drugiej stronie okna zawsze jest inna rzeczywistość niż ta, do której należy osoba sytuująca się / usytuowana po jednej ze stron, rzeczywistość rozpoznawana sensualnie. Tragiczna śmierć Korczaka i jego podopiecznych tworzy zamknięty dyskurs biograficzny, podporządkowany tutaj elemento- 
wi przestrzenno-architektonicznemu. Młody czytelnik wie już, co się stanie (również za sprawą powszechności wiedzy o życiorysie autora Króla Maciusia Pierwszego), nie jest tylko pewien: jak. W biografii Czerwińskiej-Rydel otrzymuje zatem opis prawdopodobnych sekwencji zdarzeń.

Pisarska produktywność, profesjonalizm i społeczny odbiór powieści zostały wyeksponowane w biografii Sto tysięcy kartek. Opowieść o Józefie Ignacym Kraszewskim, również autorstwa gdańskiej pisarki. Wyróżnieniu nie podlegają tutaj ramy biografii (narodziny lub śmierć), ponieważ bieg życia przedstawianego twórcy nie wymagał ich wyeksponowania. Zwrócono uwagę na cechy osobowości i warsztat pisarski Kraszewskiego, stosując metody skalarne (ilości, wielkości, doniosłości). Aktualnym dla młodego odbiorcy wątkiem pozostaje wskazanie na twórczość własna jako przeciwwagę dla odtwórczości, bierności, oraz na czytanie i pisanie książek jako czynności konkurencyjne dla elektronicznych rozrywek. W fabule opowieści nastolatek, w nadmiarze korzystający z „dobrodziejstw” elektroniki, trafia do krewnego, profesora literaturoznawcy, piszącego książkę o Kraszewskim. Wspólne zajęcia i czytanie fragmentów tej książki nie tylko zbliża bohaterów, pozwala nastolatkowi na komputerowy „odwyk” (krok po kroku), ale też daje możliwość specyficznego współtworzenia monografii uczonego (kawałek po kawałku). Chłopiec staje się pierwszym czytelnikiem i recenzentem książki wuja.

Mitobiografizm cechuje inną narrację Czerwińskiej-Rydel - Ziuk. Opowieść o Józefie Pitsudskim. Narracyjny splot z przeszłością nie polega tu na rewidowaniu faktów, ale na ich wyborze i zestawieniu ze względu na wiek projektowanego odbiorcy: „dziesięć plus”. Pisarka opiera swoją opowieść na sentymentalizacji dzieciństwa i wspólnocie emocjonalnej, próbując także wytworzyć relację bliskości: czytelnik - tytułowy bohater. Kluczowy pozostaje jednak państwotwórczy aspekt tej biografii, jej usytuowanie na granicy legendowości i dokumentalności, a nawet bliżej legendy niż dokumentu. Podobnemu przesunięciu ulegają inne bieguny kreacji osób ${ }^{39}$ w biografistyce dla dzieci i młodzieży - z przewaga indywidualności nad typowościa, zdarzeniowości nad strukturalnościa, charakterystyczności nad instrumentalnością. Pytanie o instrumentalizm pojawia się w kwestii wykorzystania tekstu biografii w edukacji czy mediach. Komercjalizacja aktywności pisarskiej biografistów łączy się też z rocznicowym charakterem ich publikacji. Większość utworów ukazała się w efekcie kolejnych lat patronackich - np. Roku Chopinowskiego (2010), Roku Korczakowskiego

${ }^{39}$ Zob. J. Sławiński, Myśli na temat: biografia pisarza jako jednostka procesu historycznoliterackiego, [w:] Biografia - geografia - kultura literacka, red. J. Ziomek, J. Sławiński, Wrocław 1975, s. 9-24. 
(2012), Roku Sienkiewiczowskiego (2016) i innych. Okazjonalność tych biografii wynika z polityki pamięci kolektywnej.

Osobne utwory, odwołujące się do rodowodu państwa polskiego i opisujące linie dynastyczne, kontynuuja tradycje prozy epickiej, a nawet wielkich narracji. Fabularne reprezentacje przeszłości sa jednocześnie interpretacja dziejów, przyjęciem określonego stylu historiograficznego. Współdziałaniu postpamięci kolektywnej (funkcjonującej m.in. na podstawie wiedzy instytucjonalnie przyswojonej) i wyobraźni sprzyja zamierzchłość zdarzeń, nieistnienie źródeł historycznych, a zatem duża nieweryfikowalność faktów. Luki, niedopowiedzenia, „białe plamy”, nierozwikłane zagadki służą budowaniu opowieści pełnych napięcia i zwrotów akcji, jak oparte na konwencjach powieści podróżniczych, przygodowych, detektywistycznych narracje Piotra Wakuły (Bjørn. Syn burzy) i Grażyny Bąkiewicz (Mówcie mi Bezprym). Obie powieści dotyczą koligacji rodzinnych piastowskich władców. Wakuła eksponuje przekonania o skandynawskim rodowodzie księcia Polan, a potem także istnieniu jego córki Świętosławy - małżonki Eryka Zwycięskiego i Swena Widłobrodowego. Bakkiewicz „odpomina” i (re)konstruuje losy pierworodnego syna Bolesława Chrobrego, który jako nastolatek bierze udział w świecie wielkiej polityki (m.in. w fabule powieści uczestniczy w transkontynentalnej podróży Ottona III), stopniowo uczy się akceptacji własnego położenia, nie zawsze rozumiejąc decyzje ojca. Doznaje krzywd od innych. Tropy ciała mieszaja się więc w narracji z fabularyzowanym biegiem historii i polityki ${ }^{40}$. Bakiewicz pozostawia bohatera w momencie, w którym przekonuje się on, że objęcie przez niego tronu po ojcu nie będzie sprawą łatwa, zanim zasłuży na miano okrutnika i zdecyduje się przejąć władzę w państwie na krótki czas. Oboje twórcy, wybierając strategię fabularyzacji, buduja swoje wielowątkowe narracje na dziejowych niedopowiedzeniach, poboczności osób i zdarzeń (choćby z polskiej perspektywy), szeroko pojętej estetyce braku - z udziałem wyobraźni komplikując ścieżki bohaterów, wyposażając ich w atrybuty i motywacje, uzupełniając bieg spraw według reguł prawdopodobieństwa. Historycznie „białe biografie” Świętosławy czy Bezpryma nabierają barw.

Z kolei wielość historycznych przekazów pisanych nie udaremniła Zuzannie Orlińskiej napisania powieści $Z$ Bożej taski Jadwiga, król. Autorka zdecydowała się na połączenie aspektów władzy i wielkiej polityki dynastycznej z motywami powieści inicjacyjnej. Dorastanie do władzy odbywa się wraz z dorastaniem do kobiecości, których ,interesy” nie zawsze idą ze sobą w parze. Obie sfery aktywności stały się źródłem dylematów dla tytułowej bohaterki,

${ }^{40}$ Koncepcję i kreację postaci w historiografii Grażyny Bąkiewicz omawia artykuł K. Wądolny-Tatar, Znakowanie ziemi. Proza historyzujaca Grażyny Bakiewicz (na podstawie powieści Mówcie mi Bezprym), [w:] Żywioły w literaturze dziecięcej. Ziemia, red. A. Czabanowska-Wróbel, K. Zabawa, Kraków 2019, s. 75-92. 
której wyjątkowość w pierwszym rzędzie warunkowała jednak dziewczęcość, a później młodokobiecość. Sygnalizował to już sam tytuł utworu, wykorzystujący formułę nominacyjna, w którym przecinek łączył i zarazem rozdzielał prywatne od oficjalnego, dzieciństwo od dojrzałej roli, ale wskazywał też na konstrukt płci i osobowości bohaterki jako fabularny zakres podstawowy.

Z transmisyjnej konfiguracji ról (gdy opowiadający to prababcia lub pradziadek oraz słuchający to prawnuczka lub prawnuk), względnie odpowiadającej czasowi dzielącemu nas od II wojny światowej w przeliczeniu na pokolenia, skorzystała Anna Janko w konstrukcji powieści Oleś i Pani Róża. Pisarka intertekstualnie odnosi się do znanej narracji epistolarnej Érica-Emmanula Schmitta Oskar i pani Róża. W historii opowiedzianej przez Janko odchodzi jednak nie mały chłopiec nieuleczalnie chory, lecz mężczyzna, który w wyniku niedołężności spowodowanej wiekiem i dolegliwościami jakby na powrót staje się dzieckiem-starcem. Przekazuje jednak opowieść o własnym życiu i wojennym dzieciństwie na Zamojszczyźnie prawnuczce Róży, która nosi imię jego wybawicielki Róży Zamoyskiej. Autorka Matej zagłady dokonała tym razem transpozycji i fuzji rzeczywistych biografii - w jakiejś części i ponownie własnej matki, poetki, Teresy Ferenc; oraz Róży i Jana Tomasza Zamoyskich, ratujących dzieci z obozu przejściowego w Zwierzyńcu. Powieściowy Oleś (później pradziadek Aleksander) jest więc figurą losu wielu Dzieci Zamojszczyzny. Wraz z przemianami pokoleń pamięć jednych przechodzi w postpamięć drugich. Janko, jako przedstawicielka tak zwanego „drugiego pokolenia”, wielokrotnie swoją twórczością potwierdzała epigenetykę traumy. Inna przedstawicielka tej generacji, Agata Tuszyńska, spożytkowała w prozie dla dzieci cudzą biografię, nie korzystając z planu doświadczeń własnej rodziny. Tym razem „rodzinna historia lęku”, by przywołać tytuł prozy Tuszyńskiej dla dorosłych, złagodzona niepełnym obrazowaniem dramatów getta, zewnętrznych wobec ukrytej w piwnicy Zosi, małej bohaterki utworu Mama zawsze wraca, wyraża nadzieję na ocalenie najważniejszych więzi międzyludzkich i relacji człowieka ze światem. Znakomite ilustracje Iwony Chmielewskiej, która z równym pietyzmem i zaangażowaniem konstruuje artystyczne obrazy dla dzieci i dorosłych, namawiając do intelektualnego i emocjonalnego odbioru, mogą nawet stanowić autonomiczną formę komunikacji o przeszłości.

Paraboliczny wymiar mają utwory podejmujące problematykę migracji. Tylko pozornie funkcjonują więc poza czasem, na prawach możliwej repetycji doświadczenia - zawsze i wszędzie. Odwołują się do uniwersalizmu problematyki „u-chodzenia” ${ }^{41} \mathrm{w}$ wymiarze negatywnym i pozytywnym, synchronicznym i diachronicznym, nawet jeśli zdarzenia sytuowane są w konkretnej

${ }^{41}$ Przywołuję tu tytuł monografii Tadeusza Sławka, U-chodzić, Katowice 2015. 
geoprzestrzeni. O problemach tych traktuje proza Katarzyny Pranić, Ewy Grętkiewicz, Barbary Gawryluk, Moniki Błądek, Rafała Witka, Jarosława Mikołajewskiego, Grzegorza Gortata. Wędrówka Nabu Mikołajewskiego jest ufundowana na baśniowej topice i zarazem ja neguje. Baśniową proweniencję zdaje się mieć nieokreśloność geograficzno-historyczna zdarzeń, samotna wędrówka małej bohaterki, motyw drogi, pokonywanie kolejnych granic fizycznych i egzystencjalnych wyobrażonych przez wielkie jezioro i jego brzegi, czy kolejne szeregi funkcyjnych postaci-aktantów: żołnierzy, policjantów, celników. Nie-baśń Mikołajewskiego konstruuja jednak negatywne doświadczenia bohaterki, brak donatorów i pomocy ze strony otoczenia, a także finałowa scena zawieszająca akcję. Nabu, stojąc na „nieswoim” brzegu jeziora, oczekuje na decyzję innych, zgodnie z którą będzie mogła się ogrzać i być może otrzyma posiłek albo znów każe się jej wejść do wody i odbyć podróż w kierunku, z którego przybyła.

Z kolei Grzegorz Gortat uczynił narratorem swojej powieści kilkuletnią mieszkankę Aleppo. Tytuł Moje cudowne dzieciństwo w Aleppo wyraża więc czas utracony, przeobrażona przestrzeń, granice okresu życia. Jednocześnie owa cudowność paradoksalnie nadal oznacza starania dorosłych o zachowanie minimum bezpieczeństwa, pozorów niewojennej egzystencji, dziecięcych zachwytów światem, prawa do nauki i zabawy. Iluzoryczność spokoju i trudnej normalności warunków życia niszczą akty przemocy: uprowadzenie i zgładzenie nauczyciela dzieci, nękanie ojca rodziny Chalimów, występujacego nierzadko w roli tłumacza, śmierć najmłodszego z rodzeństwa w wyniku wybuchu bomby-pułapki. Prześladowców uosabia krewny - stryj Husajn, co pokazuje też kręgi niebezpieczeństwa. Ramy społeczno-kulturowe opowieści przestają być dla polskiego czytelnika egzotyczne, jeśli odwołać się do podstawowych ludzkich potrzeb, posiadania rodziny i jej funkcjonowania, m.in. wobec konieczności podejmowania decyzji o uchodźctwie. Zaś narracja zyskuje sens paraboliczny, jeśli spojrzeć na kulturową powtarzalność urbicydu ${ }^{42}$, od oblężenia Troi ku XX-wiecznym blokadom i tragediom miast ówczesnego Leningradu, Sarajewa, i właśnie Aleppo. Opowieści migracyjne dla najmłodszych pokazują naruszony habitus dziecka, ale również bezbronność dorosłych, zrównanie doświadczeń pokoleń. „Obie perspektywy oglądu rzeczywistości - dziecięca i niedziecięca - zbiegają się, dając świadectwo nie tylko bezradności człowieka wobec współczesnej wojny, ale także uzmysławiają fakt przenikania się niedorosłości i dorosłości” ${ }^{43}$ - stwierdza Maciej

${ }^{42}$ Kwestie te rozważa A. Legeżyńska, Róże dla głodnych bohaterów. O dwóch wariantach sttumionego dyskursu martyrologicznego, [w:] Heroica. Bohaterstwo w literaturze i kulturze europejskiej, red. A. Gawarecka, W. Szturc, E. Wesołowska, Poznań 2019, s. 171-193.

${ }_{43}$ M. Wróblewski, Ciało dzieciństwa na wojnie. W stronę fikcji, [w:] tegoż, Doświadczenie dzieciństwa..., s. 167. 
Wróblewski, odnosząc się również do minipowieści Gortata, jak ją nazywa. $\mathrm{Z}$ pewnością narracje migracyjne dla dzieci wymagałyby literaturoznawczego opisu ze względu na doświadczenia różnych populacji w XXI wieku ${ }^{44}$. Wszystkie jednak pokazują migrację w splocie doświadczeń mowy, ciała, czasu, przestrzeni, a przede wszystkim relacji.

Wymienione i opisane przykłady literackiej historiografii dla niedorosłych odbiorców, uchwycone w kilku formalno-problemowych zakresach, dają się odczytać przez pryzmat wielu analityczno-interpretacyjnych praktyk, nakładających się na siebie i niepełnych metodologii, a retencyjny kierunek czytania, z wpisanym weń horyzontem przeszłości, nie wyklucza protencyjnego - nastawionego na przyszłość i środowiskową zmianę, motywowana postkolonialnymi rewizjami dawnych utworów, ważną problematyką XXI wieku (migracja, postpamięć), nieantropocentrycznym widzeniem rzeczywistości ${ }^{45}$. Próbę zastosowania badań nad zwierzętami, roślinami, rzeczami do opisu literatury dla dzieci i młodzieży, również w odniesieniu do utworów o przeszłości, stanowią artykuły pomieszczone w monografiach zbiorowych Czytanie menażerii czy $O$ czym mówia rzeczy? ${ }^{46}$.

Warto zwrócić też uwagę, że w dyskursie historiograficznym nowoczesnego odczytania domagają się ilustracje opowiadające historię, np. poprzez rzeczy. Znakomitym przykładem są tutaj obrazy Jolanty Richter-Magnuszewskiej do prozy Beaty Ostrowickiej Jest taka historia. Opowieść o Januszu Korczaku. Informacyjno-estetyczny ciężar przekazu bierze na siebie finałowa ilustracja o dwudzielnym charakterze - wokół torów kolejowych usytuowanych na szarym tle leżą kolorowe dziecięce zabawki, natomiast za linią demarkacyjna, oddzielająca pierwszą część ilustracji, trasa kolejowa niknie za zielonym wzgórzem. Niezwykła jest metaforyczna wymowa tego, pozbawionego osób, obrazu, przywodząca na myśl estetykę przedstawień raju, pól elizejskich, arkadyjskość, oddzielająca tragizm wojny od nadziei

${ }^{44}$ Opis taki mógłby być dokonany choćby ze względu na kategorie kontekstualizacji wypowiedzi literackiej, hybrydyczności, akulturacji i asymilacji, pamięci kultury rodzimej, nieprzekładalności kultur i inne. Proponuje je w swoim studium M. Dąbrowski, Wspótczesna literatura emigracyjna / migracyjna: rewizja pojęć analitycznych, [w:] Narodowe, regionalne, kontynentalne, światowe - literatury i dyskursy o literaturach, red. M. Skwara, Kraków 2017, s. 317-335. Na przykładzie wybranych utworów dla dzieci i młodzieży tematykę tę podjęła M. Wójcik-Dudek, Homo migrans. Miejsce literatury dla dzieci i młodzieży w edukacji empatii, „Postscriptum Polonistyczne” 2019, nr 2, s. 31-50.

${ }^{45}$ Zastosowanie perspektywy posthumanistycznej w opisie przeszłości potwierdza też zakres tematyczno-badawczy kompendium: Teoria wiedzy o przeszłości na tle wspótczesnej humanistyki. Antologia, red. E. Domańska, Poznań 2010.

${ }^{46}$ Zob. Czytanie menażerii. Zwierzęta $w$ literaturze dziecięcej, młodzieżowej i fantastycznej, red. A. Mik, P. Pokora, M. Skowera, Warszawa 2016; O czym mówiq rzeczy? Świat przedmiotów w literaturze dziecięcej i młodzieżowej, red. A. Mik, M. Niewieczerzał, E. Rąbkowska, G. Leszczyński, Warszawa 2019. 
na życie po życiu. Poza sfera porównań pozostaje tu pytanie o inspiracje filmem Andrzeja Wajdy o Korczaku, który wzbudzał w Europie kontrowersje m.in. ze względu na komunikowanie o finale egzystencji Starego Doktora $\mathrm{i}$ jego podopiecznych - w aspekcie uwolnienia czy śmierci jako wolności. Jednak to estetyczne podstawienie ilustracji w miejsce możliwych słownych wyjaśnień nie puentuje trudnego końca, nie epatuje okrucieństwem, pozostawia młodego czytelnika z domysłem śmierci bohaterów. Na uwagę zasługuje tu też cała narracja ilustracyjna rozumiana jako ciag obrazów. Wiele scen komponowanych jest jakby na obrzeżach kartek, dzieje się to z udziałem synekdochy jako tropu wizualnego. Dodatkowo porzucone zabawki, widoczne w ilustracyjnej scenie zamykającej opowieść, wcześniej mają swoich właścicieli, i wprawne oko dziecka-czytelnika bez trudu odnajdzie je we wcześniejszych obrazowych kompozycjach. Obraz znakomicie wyręcza słowo w historii o trudnym przebiegu, a przedmiot staje się medium przeszłości.

Większości omówionych w artykule zjawisk literacko-wydawniczych dotyczy „kłopot” z genologia, wynikający już z nagłówkowych deklaracji genologicznych twórców, nazywających swoje utwory „opowieściami”, które jeszcze nie sa powieściami, a już nie są opowiadaniami, choćby z powodu limitów objętościowych i delimitacji wewnątrztekstowych. Oznacza to pominięcie tradycyjnych wyznaczników genologicznych i/lub przyjęcie ogólnej formuły opowiadania jako praktyki narracyjnej. Można przyjać, że literacka historiografia dla młodego pokolenia jest realizowana głównie poprzez strategie „opowiadać na nowo” i ,opowiadać dalej”" niekiedy występujące łącznie, i dajace się poszerzyć w kierunku opcji „opowiadań inną istota”, „opowiadać przestrzenia”, „opowiadać obrazem”. Indywidualizacja opowieści i jej wyraźna adresatywność decydują w tym wypadku o narracji historycznej jako dyskursie, zawsze cechującym się określonym poziomem retoryczności i perswazyjności ${ }^{48}$. Splatanie przeszłości z teraźniejszością dziecka-czytelnika, i w zasadzie z jego przyszłościa, wydaje się koniecznym warunkiem jej interioryzacji, uznania jej za własna, przyznania się do niej. Ma ono zawsze charakter wieloczasowy, wielopokoleniowy, wielokulturowy. W szkole użycie historiografii literackiej powinno być także wieloprzedmiotowe, co wymagałoby zaangażowania i współpracy nauczycieli języka polskiego, historii, geografii i innych - dla odpowiedzialnego połączenia dziecięcego z dojrzałym, indywidualnego ze zbiorowym.

${ }^{47}$ Odnoszę się tutaj do wybranych strategii zaproponowanych przez A. Burzyńska, $K a-$ riera narracji. O zwrocie narratywistycznym whumanistyce, [w:] tejże, Anty-teoria literatury, Kraków 2006, s. 119-148.

${ }^{48} \mathrm{Na}$ te kategorie zwracał uwagę A. Smuszkiewicz, Retoryka wspótczesnej polskiej powieści historycznej dla dzieci i młodzieży, Poznań 1987. 


\section{BIBLIOGRAFIA}

Adaptacje. Szkolne użycia ponowoczesnych (anty)teorii literatury, red. G.B. Tomaszewska, D. Szczukowski, Gdańsk 2018.

Burzyńska A., Anty-teoria literatury, Kraków 2006.

Combrzyńska-Nogala D., Bezsenność Jutki, il. J. Rusinek, wyd. 2, Łódź 2011.

Cyzman M., Historia jednego drzewka. O Mirabelce Cezarego Harasimowicza z perspektywy ,zwrotu ku rzeczom” [maszynopis udostępniony przez autorkę, przeznaczony do publikacji w jednym z czasopism naukowych].

Czapliński P., Bednarek J.B., Gostyński D., Literatura i jej natury. Przewodnik ekokrytyczny dla nauczycieli i uczniów szkót średnich, Poznań 2017.

Czapliński P., Literatura i życie. Perspektywy biopoetyki, [w:] Teoria-literatura-życie. Praktykowanie teorii w humanistyce wspótczesnej, red. A. Legeżyńska, R. Nycz, Warszawa 2012, s. 63-93.

Czapliński P., Sploty, [w:] Nowa humanistyka. Zajmowanie pozycji, negocjowanie autonomii, red. P. Czapliński, R. Nycz i in., Warszawa 2017, s. 9-21.

Czerwińska-Rydel A., Listy w butelce. Opowieść o Irenie Sendlerowej, wyd. 3, Łódź 2018.

Czytanie menażerii. Zwierzęta w literaturze dziecięcej, młodzieżowej i fantastycznej, red.

A. Mik, P. Pokora, M. Skowera, Warszawa 2016.

Dauksza A., Ustanawianie świadka, [w:] Świadek: jak się staje, kim jest?, red. A. Dauksza, K. Koprowska, Warszawa 2019, s. 164-197.

Dąbrowski M., Kresy w perspektywie krytyki postkolonialnej, „Porównania” 2008, nr 5, s. $91-111$.

Dąbrowski M., Wspótczesna literatura emigracyjna / migracyjna: rewizja pojęć analitycznych, [w:] Narodowe, regionalne, kontynentalne, światowe - literatury i dyskursy o literaturach, red. M. Skwara, Kraków 2017, s. 317-335.

Dymel-Trzebiatowska H., Opowieść dla dzieci a opowieść dla dorostych. Dwie literackie odsłony Wielkiej Szpery w tódzkim getcie, [w:] (Od)pamiętywanie-gry z przeszłościa $w$ literaturze dla dzieci i młodzieży, red. B. Niesporek-Szamburska, M. Wójcik-Dudek, Katowice 2018, s. 173-186.

Gieba K., Lubuska literatura osadnicza jako narracja założycielska regionu, Kraków 2018.

Gralewicz-Wolny I., Mytych-Forajter B., Po pierwsze. O literaturze dla dzieci (i nie tylko), Kraków 2019.

Gralewicz-Wolny I., Pożegnanie Murzynka Bambo, [w:] Wyczytać świat - międzykulturowość w literaturze dla dzieci i młodzieży, red. B. Niesporek-Szamburska, M. Wójcik-Dudek, współpraca A. Zok-Smoła, Katowice 2014, s. 95-104.

Hayden White w Polsce. Fakty, krytyka, recepcja, red. E. Domańska, E. Skibiński, P. Stróżyk, Kraków 2019.

Inglot M., Murzynek Bambo Juliana Tuwima w świetle krytyki postkolonialnej i feministycznej, [w:] „Stare” $i$,nowe” w literaturze dla dzieci i mtodzieży, red. B. Olszewska, E. Łucka-Zając, Opole 2010, s. 37-48.

Jakowska K., O cyklu opowiadań. Z teorii i historii cyklu narracyjnego $w$ Polsce, Białystok 2011.

Jarzyna A., O czym myślę, kiedy myślę o zwierzętach w edukacji polonistycznej? Siedem odpowiedzi, „Polonistyka. Innowacje” 2020, nr 11, s. 63-76. 
Jarzyna A., Szlemiele. Zwierzęta wobec Zagłady w literaturze dla dzieci, „Narracje o Zagładzie" 2016, nr 2, s. 235-256.

Kłakówna A.Z., Przymus i wolność. Projektowanie procesu ksztatcenia kulturowej kompetencji. Język polski w klasach IV-VI szkoty podstawowej, w gimnazjum i liceum, Kraków 2003.

Kobielska M., Polska kultura pamięci w XXI wieku: dominanty. Zbrodnia katyńska, powstanie warszawskie $i$ stan wojenny, Warszawa 2016.

Koziołek K., Ziemia niczyja. Zwroty badawcze w literaturoznawstwie i ich konsekwencje dla nauczania literatury, „Postscriptum Polonistyczne” 2012, nr 2, s. 109-126.

Kwiatkowska A., Korzenie pamięci. O Mirabelce Cezarego Harasimowicza, „Paidia i Literatura” 2020, nr 2, s. 67-76.

Lasoń-Kochańska G., Gender w literaturze dla dzieci i młodzieży. Wzorce ptciowe i kobiecy repertuar topiczny, Słupsk 2012.

Legeżyńska A., Róże dla głodnych bohaterów. O dwóch wariantach sttumionego dyskursu martyrologicznego, [w:] Heroica. Bohaterstwo w literaturze i kulturze europejskiej, red. A. Gawarecka, W. Szturc, E. Wesołowska, Poznań 2019, s. 171-193.

Leociak J., Doświadczenia graniczne. Studia o dwudziestowiecznych formach reprezentacji, wyd. 2 popr., Warszawa 2018.

Moskalewicz M., „Murzynek Bambo - czarny, wesoty...”. Próba postkolonialnej interpretacji tekstu, „Teksty Drugie” 2005, nr 1-2, s. 259-270.

Muchowski J., Polityka pisarstwa historycznego. Refleksja teoretyczna Haydena White'a, Toruń 2015.

O czym mówiq rzeczy? Świat przedmiotów w literaturze dziecięcej i młodzieżowej, red. A. Mik, M. Niewieczerzał, E. Rąbkowska, G. Leszczyński, Warszawa 2019.

Ochwat M., (Wspót)myślenie w humanistyce. Literackie ekoksztatcenie w epoce antropocenu, „Polonistyka. Innowacje” 2020, nr 12, s. 31-52.

Piątkowska R., Wszystkie moje mamy, il. M. Szymanowicz, wyd. 2, Łódź 2014.

Pietrych K., (Re)prezentacje czy symulacje? Przestrzeń tódzkiego getta w literaturze XXI wieku, [w:] Geograficzne przestrzenie utekstowione, red. B. Karwowska, E. Konończuk, E. Sidoruk, E. Wampuszyc, Białystok 2017, s. 309-330.

(Re)konstrukcje przeszłości w prozie Antoniny Domańskiej, red. M. Chrobak, K. Wądolny-Tatar, Kraków 2019.

Rusinek M., Zaklęcie na „w”, il. J. Rusinek, Łódź 2011.

Rybak K., Dzieciństwo w labiryncie getta. Recepcja mitu labiryntu w polskiej literaturze dziecięcej o Zagtadzie, Warszawa 2019.

Ryrych K., Mała wojna, Łódź 2019.

Siewior K., Osadzanie. O dyskursie Ziem Odzyskanych, [w:] tejże, Wielkie poruszenie. Pojałtańskie narracje migracyjne w kulturze polskiej, Warszawa 2018, s. 64-94.

Skotnicka G., Barwy przeszłości. O powieściach historycznych dla dzieci i młodzieży 1939-1989, Gdańsk 2008.

Skórczewski D., Teoria - literatura - dyskurs. Pejzaż postkolonialny, Lublin 2013.

Sławek T., U-chodzić, Katowice 2015.

Sławiński J., Myśli na temat: biografia pisarza jako jednostka procesu historycznoliterackiego, [w:] Biografia-geografia-kultura literacka, red. J. Ziomek, J. Sławiński, Wrocław 1975, s. 9-24. 
Smuszkiewicz A., Retoryka wspótczesnej polskiej powieści historycznej dla dzieci i młodzieży, Poznań 1987.

Smykowski M., Ekologiczne świadectwo Zagtady. Repatriacja mirabelki na Muranów, [w:] Świadek: jak się staje, czym jest?, red. A. Dauksza, K. Koprowska, Warszawa 2019, s. 278-291.

Starnawska K., Agata jako „człowiek ekologiczny”. Lustro pana Grymsa Doroty Terakowskiej w lustrze ekokrytyki, [w:] Imaginautka zaangażowana. Twórczość i biografia Doroty Terakowskiej z perspektywy XXI wieku, red. K. Slany, K. Wądolny-Tatar, Kraków 2021 [w druku].

Strękowska-Zaremba M., Zagner-Kołat J., Królewskie życie królów, Łódź 2019.

Teoria wiedzy o przeszłości na tle wspótczesnej humanistyki. Antologia, red. E. Domańska, Poznań 2010.

Tomalak B., Postkolonializm w literaturze młodzieżowej, czyli... mamy problem!, „Świat i Słowo" 2017, nr 2, s. 87-103.

Tomaszewska G.B., Praktyki czytania. Ponowoczesna interpretacja a szkoła, Gdańsk 2019.

Topolski J., Wolność i przymus w tworzeniu historii, wyd. 2, Poznań 2004.

Tramer M., Bambo zrobit swoje, „Acta Universitatis Lodziensis. Folia Litteraria Polonica" 2014, nr 4, s. 149-160.

Wądolny-Tatar K., Znakowanie ziemi. Proza historyzujaca Grażyny Bakiewicz (na podstawie powieści Mówcie mi Bezprym), [w:] Żywioty w literaturze dziecięcej. Ziemia, red. A. Czabanowska-Wróbel, K. Zabawa, Kraków 2019, s. 75-92.

Wójcik-Dudek M., Homo migrans. Miejsce literatury dla dzieci i młodzieży w edukacji empatii, „Postscriptum Polonistyczne” 2019, nr 2, s. 31-50.

Wójcik-Dudek M., W(y)czytać Zagtadę. Praktyki postpamięci w polskiej literaturze XXI wieku dla dzieci i młodzieży, Katowice 2016.

Wróblewski M., Doświadczenie dzieciństwa. Studium z antropologii literatury, Toruń 2019.

Żółkoś M., Łowcy kultur. Cykl powieściowy o Tomku Wilmowskim w świetle myśli postkolonialnej, [w:] Studia postkolonialne nad kulturq i cywilizacja polska, red. K. Stępnik, D. Trześniowski, Lublin 2010, s. 347-358.

„Zwroty” badawcze w humanistyce. Konteksty poznawcze, kulturowe i spoteczno-instytucjonalne, red. J. Kowalewski, W. Piasek, Olsztyn 2010. 
